\title{
Examining the image of nursing among the children hospitalized in the oncology ward
}

\begin{abstract}
Introduction. Patients, as subjects of medical care, are becoming increasingly more demanding toward medical professionals which poses a challenge both for doctors and nurses. A variety of factors influences the professional image of a nurse. Different features are involved, including the nurse's professional or interpersonal skills their personal beliefs, attitude, as well as social stereotypes about nurses.

Aim. Looking at the image of nursing among the children hospitalized in the oncology ward.

Material and methods. The authors used both literature review and a questionnaire of their own making. The literature review was done using data from the databases of Polish Central Medical Library. The research group comprised 32 children (aged from 8 to 17), all undergoing hospitalization in Hematology/Oncology and Child Transplantology in Lublin. The statistical calculations are made using $\mathrm{Chi}^{2}$ tests. The test results of $\mathrm{p}<0.05$ were held as statistically significant.

Results. The group was mostly composed of children aged 14 to $17(56.25 \%)$. There were more boys (62.5\%) than girls. The majority of children came from rural areas (71.87\%) and most of them read through the documentation concerning the rules of the ward. Both nurses" work and relations with patients were graded as "good" by the patients. Children pointed to "nice appearance" as the most important feature of every nurse.

Discussion. A pediatric nurse should be patient, have lots of understanding, be sympathetic, caring and able to hold their nerve. Unfortunately, according to authors of earlier studies, not all nurses have these traits. This is due to the fact that the staff rarely involve in communication with the patients and they lack interpersonal skills.

Conclusions. Children have a very high opinion on the work of nurses at the Hematology/Oncology and Child Transplantology Clinics. The children emphasized that the following features have the highest impact on their picture of the nurse: nice looks, being protective and caring. A research study conducted at the Hematology/Oncology and Child Transplantology Clinics shows the right features that a nurse should have.
\end{abstract}

Keywords: children, nurses, opinions, professional image of a nurse.

DOI: $10.1515 /$ pjph-2015-0031

\section{INTRODUCTION}

The professional image of a nurse is influenced by: people's beliefs, opinions and stereotypes about that group [1]. The way the professional image of a nurse is shaped, influences the human relationships in the society. It goes without saying that the overall social perception of nurses hugely affects patients' emotions which means that it should be as positive as possible $[1,2]$. Furthermore, the following features are essential for building a professional image of a nurse: social attitude (prestige), professional skills (ability to work hard, being resourceful, one's education, conscientiousness and independence), personal skills (e.g. sensitivity, neatness, mental strength, good behavior, patience,) interpersonal features (e.g. ability to build trust, openness, being talkative and understanding toward others) $[2,3]$.

The right professional image exerts huge influence over the profession's status. This rings true both for medical and non-medical jobs. A literature review shows that in Poland, which is similar to what is happening in the United States, there is huge social respect for nurses, even though the profession itself is not deemed too attractive. A few Gallup polls conducted in the US indicate that nurses are considered to be the most ethical and decent professionals. According to the same research, American nurses placed first in that respect $[2,4]$.

\footnotetext{
${ }^{1}$ Hematology/Oncology and Child Transplantology Clinic, Medical University of Lublin, Poland

${ }^{2}$ Emergency Department, Cardinal Stefan Wyszynski Regional Specialist Hospital in Lublin, Poland

${ }^{3}$ Royal Albert Edward Infirmary, Wigan, United Kingdom

${ }^{4}$ York University, Toronto, Canada

${ }^{5}$ Chair and Department of Obstetrics and Perinatology, Medical University of Lublin, Poland

${ }^{6}$ Lung Disease and Child Reumatology Clinic, Medical University of Lublin, Poland
} 
There is an increasing number of children affected by oncologic problems. Onset of such problems immediately calls for a long-lasting hospitalization process which makes children feel unsafe, causes stress and negatively affects their daily life, both at home and school. All patients, no matter what their age is, need the medical stuff to show support and understand them. The nurse becomes a source of knowledge about medicine, stemming from both her work experience and education. As Koper and Wrońska (2003) suggest, curing tumors is not that much about the therapy itself but also early and successful diagnosis, involvement of the medical staff (nurses are responsible for preparing the child for hospitalization, making parents aware of how to care for a sick child both at home or in the hospital, in the period between different stages of the curing process. This is why the standards and algorithms of therapy have been designed to suit the needs of parents and children. It needs emphasizing that a nurse is not only a caretaker, psychologist or a spare mother but she is also responsible for doing check-ups, assisting the doctor during bone marrow aspiration, trepanobiopsy, lumbar punctures or bonemarrow transplant. Nurses should also engage in some other activities, like organizing patients' free time $[5,6]$.

The work of a pediatric nurse is a huge challenge since the nurse has to take care of the child as well as their family. Here, factors like the child's biological, psychological or social status come into play, as well as the facility in which the care is provided [7].

\section{AIM}

Examining the image of nursing among the children hospitalized in the oncology ward.

\section{MATERIAL AND METHODS}

The research was made on the child patients staying at the Hematology/Oncology and Child Transplantology Clinic of Prof. Antoni Gębala Children's Hospital of Lublin. The group consisted of children undergoing hospitalization lasting because of tumors for at least 3 weeks. A questionnaire of the authors' own making was used in the study. It included 20 questions, divided into 4 groups. The first part was a survey ( 5 questions) about the age, sex, place of residence, school and family. The second part consisted of open questions (6 to 9) looking at the expectations of children regarding their acceptance of the conditions in the hospital. The third part included questions from 10 to 17 , looking at personal traits of a nurse, their looks (protective clothes, hairdo, make-up), respecting patients' rights, providing intimate conditions, as well as doing the basic work. The remaining questions (18-20) looked at nurses' communication with patients and their parents, fulfilling physical needs, availability of the medical staff during shifts and the quality of care provided. Also, the children were inquired about how long did they have to wait for all the procedures to be completed ("short time" 30-40 minutes, "relatively long time" 40-60 minutes, "long time" over 60 minutes.) A numeric scale (from 1 to 4) was used in order to make it easier for the respondents to provide answers: 1 means "very bad", 2 "bad",
3 "good', 4 "very good". Every child was informed about the purpose of the study, as well as about the fact that it is anonymous and voluntary. The research was done according to the rules of personal data protection, valid for Professor Antoni Gębala Children's Hospital of Lublin. The results were then subject to a statistical analysis. The values of the measurable parameters are shown using an arithmetic mean, a median, as well as minimal or maximal values. At the same time, non-measurable units are presented using cardinality and interest. A chi-square test was used for finding differences between the two compared groups. For measurable values, the U Mana-Whitney test was used, and in cases where there were more than two groups involved, the Kruskal-Wallis test was implemented. The correlation and dependence Spearman method was used to check the relationships between some variables. The statistical significance was determined at $p<0.05$, showing that there are some statistically significant differences or dependencies. The database as well as the statistical research were done using the Statistica 9.1 software (by StatSoft, Poland).

\section{RESULTS}

Some 40 surveys were handed out, out of which 32 were filled out correctly (meaning, all questions answered) whilst the remaining 8 were filled incorrectly (e.g. every third question was unanswered or even not marked at all.) The research was done in 2012 on the Hematology/Oncology and Child Transplantology Ward of Prof. Antoni Gębala Children's Hospital of Lublin. The group that was looked at mostly consisted of boys $(62.5 \%)$, while girls were some $37.5 \%$. Most children were aged between 14 and 17 (56.25\%) while younger children ( 8 to 13 ) consisted $43.75 \%$. Some $40.63 \%$ of the participants attended a primary school, 28.13 high school, and $31.25 \%$ secondary school (gimnazjum in Polish). Most of those surveyed were rural residents (71.87\%), around $18.75 \%$ were residents small town with less than 20000 inhabitants, while $9.38 \%$ lived in cities with more than 100000 people. The data is shown in the table below.

TABLE 1. Sociodemographic data.

\begin{tabular}{lcc}
\hline \hline \multicolumn{2}{l}{ Sex } \\
\hline boys & & $62.50 \%$ \\
\hline girls & Age & $37.50 \%$ \\
\hline \multicolumn{2}{l}{} & \\
\hline $8-13$ & School & \\
\hline $14-17$ & $56.75 \%$ \\
\hline \multicolumn{2}{l}{} & $40.63 \%$ \\
\hline Primary school & $31.25 \%$ \\
\hline Secondary school & $28.13 \%$ \\
\hline High school & \\
\hline \multicolumn{2}{c}{ Place of residence } \\
\hline Rural area & $71.87 \%$ \\
\hline Small town & $18.75 \%$ \\
\hline Big city & $9.38 \%$ \\
\hline
\end{tabular}


Most of the surveyed children had a chance to look at the documentation used in the ward $-87.50 \%$ were acquainted with the topography of the ward, $84,38 \%$ read the ward's code of conduct, while some $71.88 \%$ read about the daily schedule. The data is shown in Figure 1.

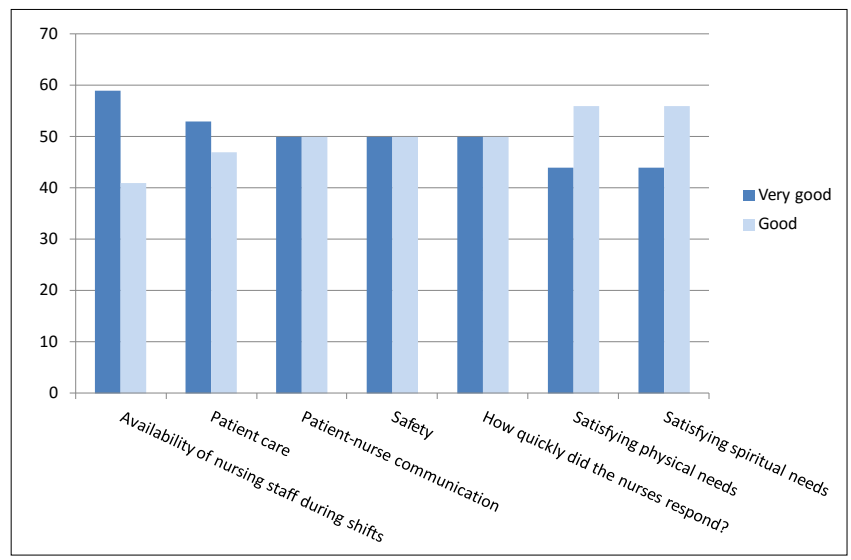

FIGURE 1. The expectation of children regarding the conditions in a hospital.

Every child received support whenever they felt fear or anxiety. They were also assisted when preparing for the diagnostic check-ups. In both cases, the values reached $100 \%$.

The participants of the study pointed to the following features as most important: nice looks (warm, sympathetic) $100 \%$, caring (thoughtful, caring) $-71.88 \%$, open-hearted, friendly, polite). The feature "nice looks" was most frequently mentioned by the respondents (Figure 2).

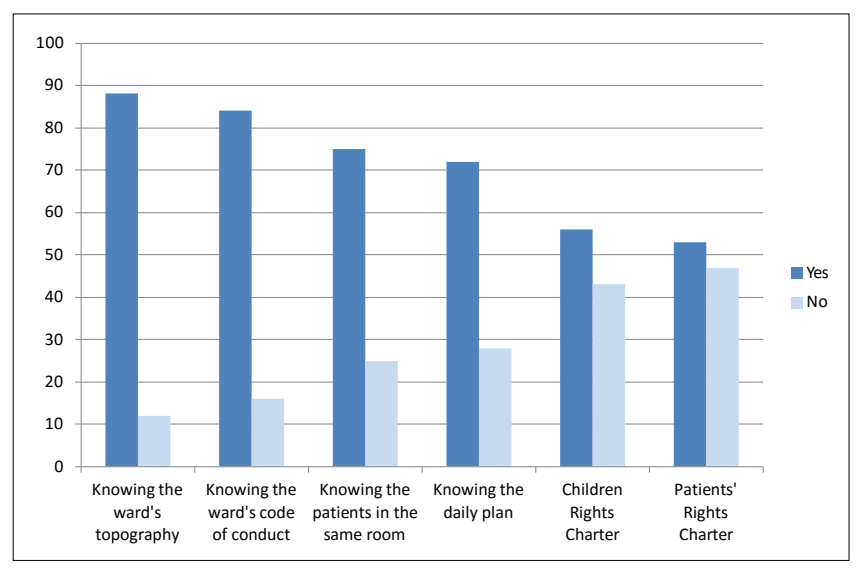

FIGURE 2. How children assessed nurses' personal features.

Some $53.12 \%$ of the respondents provided a "very good" mark for the work of the medical staff, while $46.88 \%$ felt it was "good". A half of the study participants graded the nurse-patient communication as "very good" while another half claimed it was "good".

According to some $59.37 \%$ of children, one's looks is very important whilst $74.97 \%$ claim that wearing protective clothes is an essential part of the job.

Children also voiced their satisfaction about the care they received. This section looked at issues like the availability of the nursing staff during shifts - graded "very good" by $59.38 \%$ and "good" by $40.63 \%$. The patient care was graded "very good" (53.12\%) and "good" by $46.88 \%$ of the respondents. The study also looked at the patient-nurse communication
- the results were distributed evenly. Similar results were obtained in sections looking at how the patient's safety was ensured and how quickly did the medical staff respond to patient's needs. When it comes to fulfilling the physical needs - $43.74 \%$ gave a "very good" grade while $56.25 \%$ gave a "good" one. Regarding fulfilling spiritual needs, the findings were almost identical. These values are not statistically significant (Figure 3).

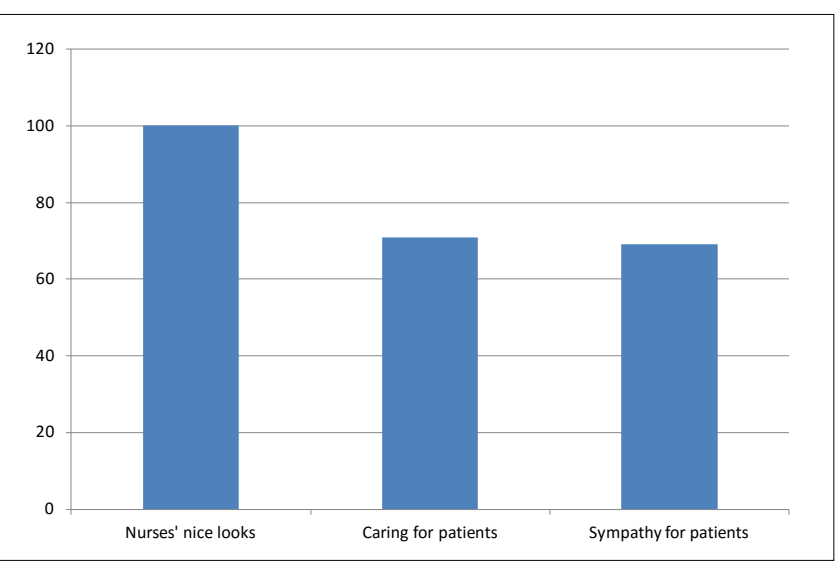

FIGURE 3. Children satisfaction from the care.

Children were also inquired about the amount of time that the nurse spends on the therapeutic procedures during a shift. There were different responses, ranging from "too little time" (40.52\%), "just enough time” (36.25\%), ,a lot of time" $(23.23 \%)$. These differences were not statistically significant.

\section{DISCUSSION}

A nurse taking care of a child is obliged to enable the children (in case of younger ones, both the children and their parents) with the Patient Charter, the ward's code of conduct, day schedules and the structure of the ward. Also, nurses introduce new patients to other children. According to the authors' own research, most children learned about the ward's structure, code of conduct and met other patients of the same ward. However, only around $50 \%$ of children had an opportunity to read the Patient Charter. According to Dróżdż et al, some 50 to $80 \%$ of children received information about their rights and obligations [8,9]. Twarduś et al claim that some $60 \%$ of nurses did not get to know patients' right, while $53 \%$ failed to tell the patients about the wards' code of conduct or daily schedule $[10,11]$. This might be due to the fact that the nurses had too many obligations, their work was poorly organized, they lacked communication skills which discouraged them to become involved and it is also possible that patients were not willing to know that.

Kuna and Tymecka proved that a pediatric nurse should be: patient, calm, full of understanding, caring and sympathetic [6]. This is confirmed by the findings of the authors of this study. The most important features that a nurse should have are "nice appearance" (100\%), caring (71.88\%) sympathy for other $(68.75 \%)$. The way a pediatric nurse communicates with the patients is also important. They should be able to inquire about their own health and receive answers they are going to understand [12]. Nurse-patient communication, 
when done in the right way, is a good basis for providing care at the best level. The authors' research shows that the participants assessed the nurses' communication skills as "very good".

Kapała and Drygas show that patients expect nurses to be professional, able to care for them all the time, be sympathetic and understand their needs or fulfill them $[6,13]$. The research confirms that the expectations of sick children, including the availability of the nursing staff during a shift, patient care, quick reactions to patients' needs, nurse-patient communication, fulfilling the patients' physical and spiritual needs were fulfilled. The key here is that the nurse should understand the therapeutic and diagnostic procedures essential in caring for children suffering from hemato-oncological diseases. These include: obtaining the material for research, caring for central venuous catheter, assisting by bone marrow aspiration, trepanobiopsy, lumbar puncture, cross section of the bone marrow, application of chemotherapy, etc. These actions are obviously made in different moments and doing them successfully depends on a couple of factors: number of nurses AT work, number of children AT the ward, behavior of parents, and so on. Most sick individuals point to the fact that these actions take around 30-60 minutes daily. Such amount of time seems insufficient for a nurse to fulfill all her duties during one shift. An analysis of a hospital logbook proves that the exact amount of the actual paperwork is somewhere around $1 \mathrm{~h}$ to $1.15 \mathrm{~h}$. Also, it needs to be remembered that dealing with the documentation is also included.

\section{CONCLUSIONS}

An analysis and interpretation of the research suggests the following:

1. The children treated at the Hematology/Oncology and Child Transplantology Clinic assess the nurses' work very well.

2. According to children, nurses should "look nice" and they should be "caring" and "sympathetic".

3. The looks of the nurse affects the way children assess them. It might be said that children put most emphasis on the looks.

To sum up, nursing care provided in the right way is essential for a successful therapeutic process. Each and every nurse builds their own image on a daily basis - through their behavior, looks and work. The nurses employed at Hematology/Oncology and Child Transplantology Clinic have all the features that a good pediatric nurse should have.

\section{REFERENCES:}

1. Obuchowska I. Pielęgniarka a chore dziecko. In: B. Pawlaczyk (ed). Pielęgniarstwo pediatryczne. Podręcznik dla studentów medycznych. Warszawa: PZWL; 2007. p. 23-6.

2. Koper A, Wrońska I (ed). Problemy pielęgnacyjne pacjenta $\mathrm{z}$ chorobą nowotworową. Lublin: Czelej; 2003.

3. Wysocki M, Czerwonka-Szeflarska M.:Pediatria i pielęgniarstwo pediatryczne-dziecko w zdrowiu i chorobie. Wybane zagadnienia. Bydgoszcz: Akademia Medyczna im. Ludwika Rydygiera; 2004.

4. Marć M. Komunikowanie jako element opieki pielęgniarskiej nad dzieckiem i rodzicami w oddziale szpitalnym. Materiały konferencyjne. Standaryzacja opieki zdrowotnej (25-27 kwietnia 2001 r.). Kraków; 2001. p. 193-7.

5. Kuna J, Tymecka I. Czynniki wpływające na pełnienie roli ekspresyjnej przez pielęgniarkę pediatryczną. Prob Szkol Nauk. 1983;3-4:41-5.

6. Mee C. Painting a portrait: how you canshape nursing $\varnothing \mathrm{s}$ image. Imprint.2006;53(5):44-9.

7. [htpp://www.gallup.com/poll/1654/honesty-ethics-professions.aspx]

8. Dróżdż Z, Dewerenda M, Pawlaczyk B. Obecność rodziców w czasie hospitalizacji dziecka-opinie personelu. Postępy Pielęgniarstwa i Promocji Zdrowia. II Międzynarodowy Kongres Edukacji w Pielęgniarstwie i Innych Naukach o Zdrowiu. Poznań: 1999;15:320-30.

9. Kojder E, Zarzycka D. Wizerunek zawodowy pielęgniarki i jego determinanty. Pielęg XXI w. 2014;2(47):47-52.

10. Twarduś K, Gaweł G, Kin-Dąbrowska J. Satysfakcja pacjentów i pielęgniarek z jakości opieki pielęgniarskiej. Probl Pielęg. 2002;1/2:221-32.

11. Włodarczyk D, Tobolska B. Wizerunek zawodu pielęgniarki z perspektywy lekarzy, pacjentów i pielęgniarek. Med Pracy. 2011;62(3):269-79.

12. Nyklewicz W. Wizerunek zawodowy pielęgniarki. Udawanie czy profesjonalizm. Mag Piel Poł. 2005;4 10-1.

13. Przybysz A, Dróżdż Z, Pawelczyk B. Jakość opieki pielęgniarskiej w oddziałach pediatrycznych. Piel Poł. 2001;2:301-3.

\section{Corresponding author}

Agnieszka Wańkowicz

21/4 Zygmunta Augusta Str., 20-283 Lublin

tel: $511-05-28-73$

E-mail: aga.wankowicz@gmail.com 